\title{
КОРЕЛАЦИЈА ПОМЕЃУ СРЕДНИОТ АРТЕРИСКИ ПРИТИСОК (МАР) И МОЗОЧНАТА САТУРАЦИЈА (RSO2) КАЈ ПАЦИЕНТИ ПОДЛОЖЕНИ НА ХИПОТЕНЗИВНА ОПШТА АНЕСТЕЗИЈА ПРИ СЕПТО- И РИНОПЛАСТИКА
}

\author{
Силвана Кралева, Билјана Ширгоска², Радмила Трајкова ${ }^{1}$ Ивана Клишеска-Илчевска ${ }^{1}$ \\ ГОБ „8-миСеӣ̄ември", Скойје, Рейублика Северна Макеgонија, \\ Универзииеейска клиника за уво, нос и г̄рло, Скойје, Рейублика Северна Макеgонија,
}

\begin{abstract}
Цитирање: Кралева С, Ширгоска Б, Трајкова Р, Клишеска-Илчевска И. Корелација помегу сред ниот артериски притисок (МАР) и мозочната сатурација (rSO2) кај пациенти подложени на хипотензивна општа анестезија при септо- и ринопластика. Арх J Здравје 2019;11(1):77-88

Клучни зборови: хипотензивна анестезија, мозоч-на оксигенација, општа анестезија, рино/ септоп-ластика

*Кореспонденција: Силвана Кралева, ГОБ „,8-миСептември”, Скопје, Република Северна Македонија. E-mail: silvanakraleva@yahoo.com

Примено: 8-јан-2019; Ревидирано: 20-фев-2019; Прифатено: 28-фев-2019; Објавено: 15-мар-2019

Печатарски права: 2019 Силвана Кралева. Оваа статија е со отворен пристап дистрибуирана под условите на нелокализирана лиценца, која овозможува неограничена употреба, дистрибуција и репродукција на било кој медиум, доколку се цитираат оригиналниот(ите) автор(и) и изворот.

Конкурентски интереси: Авторот изјавува дека нема конкурентски интереси.
\end{abstract}

\section{Извадок}

Хипотензивната анестезија е таква анестезиолошка техника при која средниот артериски притисок на пациентот се намалува за повеќе од 20\% од неговата предоперативна вредност. Мотив: да се спречи појава на хипооксија на мозокот при употреба на хипотензивна анестезиолошка техника кај пациенти подложни на септо/ринопластика. Цели на трудот: да се утврди просечната вредност на мозочната сатурација кај будни пациенти, да се одреди корелацијата на средниот артериски притисок и мозочната сатурација при умерена хипотензија, и да се анализираат постоперативните несакани ефекти. Материјали и методи: во студијата беа вклучени 20 пациенти, АСА 1, водени со умерена хипотензивна анестезија предизвикана со ремифентанил и севофлуран. Во пет временски интервали (T1-T5) се следеа параметрите: MAP, HR, rSO2 и се одреди нивната корелација. Резултати: умерена хипотензија се постигна во Т4 (MAP=69,05ะ7,09). За просечна базална вредност на мозочната сатурација се утврдија: 73,30 \pm 5,44\% за левата и 75,30ะ5,18\% за десната мозочна хемисфера. Кривата на мозочната сатурација покажуваше нагорен тренд и пик кој се совпаѓаше со воведот во анестезија, а во понатамошниот тек тенденција кон опаѓање. Се најде слаба до умерена позитивна корелација помеѓ МАР и rSO2 во текот на хипотензивната анестезија, а во целиот тек на мерењето rSO2 беше повисоко од базалната вредност. Заклучок: умерената хипотензија и стабилниот среден артериски притисок придонесуваат за стабилна мозочна сатурација.

CLINICAL SCIENCE

\section{CORRELATION BETWEEN MEAN ARTERIAL PRESSURE (MAP) AND BRAIN SATURATION (RSO2) IN PATIENTS UNDERGOING MODERATE HYPOTENSIVE ANESTHESIA FOR SEPTO- AND RHINOPLASTIC SURGERY}

\section{Silvana Kraleva ${ }^{1}$, Biljana Shirgoska², Radmila Trajkova ${ }^{1}$, Ivana Klisheska Ilcevska ${ }^{1}$}

\section{General City Hospital "8thSeptember"Skopje, Republic of North Macedonia}

Clinic for Ear, Nose and Throat Surgery, Skopje, Republic of North Macedonia

\section{Abstract}

Citation: Kraleva S, Shirgoska B, Trajkova R, Klisheska Ilcevska I. Correlation between mean arterial pressure (MAP) and brain saturation rSO2) in patients undergoing moderate hypotensive anesthesia for septo- and rhinoplastic surgery. Arch Pub Health 2019; 11 (1): 77-88 (Macedonian)

Key words: hypotensive anesthesia, brain oxygenation, general anesthesia, rhinoseptoplasty *Correspondence: Silvana Kraleva, General City Hospital "8thSeptember" Skopje, Republic of North Macedonia. E-mail:silvanakraleva@yahoo. com

Received: 8-Jan-2019; Revised: 20-Feb-2019 Accepted: 28-Feb-2019; Published: 15-Mar-2019 Copyright: ${ }^{\circ}$ 2019. Silvana Kraleva. This is an open-access article distributed under the terms of the Creative Commons Attribution License, which permits unrestricted use, distribution, and reproduction in any medium, provided the original author(s) and source are credited.

Competing Interests: The author have declared

Hypotensive anesthesia is such anesthetic technique where during general anesthesia the patient's mean arterial pressure is decreased by more than $20 \%$ of its preoperative value. Motivation: To prevent the occurrence of brain hypoxia during hypotensive anesthesia in patients undergoing septo- and rhinoplastic surgery. Aims: To determine the average values of brain saturation in awaken patients; to find the correlation between the mean arterial pressure and brain saturation during moderate hypotension, and to analyze the adverse reactions postoperatively. Materials and methods: Twenty (ASA 1) patients, anaesthetised in moderate hypotensive general anesthesia with Remifentanyl and Sevoflurane were enrolled in the study. They were observed at five times interval (T1-5): MAP, HR and rSO2, and a correlation between the parameters was determined. Results: A moderate hypotension was achieved in T4 $(\mathrm{MAP}=69.05 \pm 7.09)$. The average baseline values of brain saturation from $73.30 \pm 5.44 \%$ to the left, $75.30 \pm 5.18 \%$ to the right brain hemisphere were obtained. The curve of brain saturation had an upward trend, a peak that coincided with an introduction to anesthesia, in a further course with a downward trend. We found a mild to moderate positive correlation between MAP and rSO2 during hypotensive anesthesia, but throughout the entire period there was a higher rSO2 than the basal initial value. Conclusion: Moderate hypotension and stable mean arterial pressure (MAP) contribute to stable brain saturation (rSO2).

that no competing interests 


\section{Вовед}

Хипотензивната анестезија е анестезиолошка техника при која во текот на општата анестезија средниот артериски притисок на пациентот се намалува за повеќе од 20\% од предоперативната вредност на средниот артериски притисок ${ }^{1}$. Главен параметар се смета вредноста на средниот артериски притисок (МАР) кој треба да се одржува во рамките помеѓу 50$60 \mathrm{mmHg}$. Секое намалување под 50 $\mathrm{mmHg}$ може да доведе до оштетување на органите ${ }^{1}$. Оваа техника се користи при хируршки интервенции проследени со големо хируршко крвавење во оперативното поле или кога се работи под микроскоп, како што се интервенциите во неврохирургијата и оториноларингологијата ${ }^{1-11}$.

Според вредноста на средниот артериски притисок (МАР), постојат три степени на контролирана хипотензија:

1. блага хипотензија каде МАР се движи од 80-120 mmHg,

2. умерена хипотензија каде MAP се движи од 60-80 mmHg,

3. длабока хипотензија каде МАР изнесува $50 \mathrm{mmHg}$.

Доброто водење на мозочната перфузија и оксигенација е еден од главните принципи на сите анестезиолошки техники. И покрај тоа, мозокот сѐуште е еден од најмалку мониторираните органи во клиничката анестезија12,13. Мозочната авторегулација го одржува мозочниот крвен проток нормален во граници на среден артериски притисок (МАР) од 50-150 $\mathrm{mmHg}^{14}$, во следниот однос: CPP = MAP - ICP.

Од овој градиент всушност зависи мозочниот крвен проток (cerebral blood flow-CBF), односно кислородниот и метаболичкиот дотур на мозокот. Тоа значи дека соодветната мозочна перфузија и оксигенација (rSO2) е во корелација со вредноста на средниот артериски притисок (МАР) $)^{15,16}$.

Во последните неколку декади се овозможи да се следи мозочната оксигенација (сатурација) со помош на NIRS технологијата (Near infra-red Spectroscopy) или мозочен оксиметар. Тоа е неин- вазивен, континуиран мониторинг чијашто функција се базира врз користење на инфрацрвеното светло и овозможува мерење и следење на мозочната ткивна оксигенација $(\mathrm{rSO} 2)^{12,13,17-19}$ и нејзините промени дури и кога параметрите на системската циркулација се сѐ уште во нормалните граници ${ }^{20-22}$. Притоа, овде се мери односот на оксигенираниот хемоглобин во однос на вкупниот хемоглобин при што вредноста се изразува во проценти (\%), а соодносот помеѓу венската и артериската крв е 75\% : 25\% 23. Нормалните вредности се движат од 55\% до 80\%. По поставувањето на базалната вредност на мозочната сатурација, сите понатамошни мерени вредности на $\mathrm{rSO} 2$ се претставуваат и споредуваат со почетната вредност. Дозволениот пад на мозочната сатурација во однос на почетната базална вредност е до 20\%. Но, доколку базалната вредност е помала од 50\%, во текот на контролираната хипотензија се дозволува пад до 15\% од почетната вредност.

Притоа треба да се земат предвид неколку фактори кои влијаат врз измерената вредност на rSO2 co NIRS мониторингот. Тоа се: позиција на пациентот (поткренат горен дел на телото за 300, седечка позиција) ${ }^{24}, \mathrm{PaCO}^{25}$, концентрација на хемоглобинот $(\mathrm{Hct}<30 \%)^{26,27}$, хипо- и хипертермија ${ }^{28}$, ICP29, MAР ${ }^{29}$, како и примена на анестетици кои го намалуваат мозочниот крвен проток (Cerebral blood flow-CBF) и мозочната потрошувачка на кислород (Cerebral metabolic rate - CMRO2) зависно од дозата, со што се зголемува вредноста на $\mathrm{rSO}{ }^{17}$.

Во клиничката пракса, овој мониторинг се употребува кај голем број хируршки интервенции како што се оние во кардиоваскуларната хирургија ${ }^{30}$, хирургија во седната положба ${ }^{13}$, голема абдоминална хирургија, како и при интервенции кога е потребна умерена хипотензивна анестезија ${ }^{9,10,20}$.

Хипотензивната анестезија е техника од избор за оперативните интервенции на носот и параназалните синуси, каде доколку се изведува остеотомија на назалните коски може да предизвика хемодинамски одговор на организмот, 
како што е зголемување на крвниот притисок, зголемување на пулсот, а со тоа и зголемено крвавење во оперативното поле ${ }^{10}$. Примената на хипотензивна анестезија претставува индикација за употребата на NIRS мониторот.

Основен мотив на ова истражување беше да се спречи појавата на хипоксија на мозокот поради ткивна хипоперфузија при употреба на хипотензивна анестезиолошка техника кај пациенти кои беа подложени на септои ринопластика.

Целта на оваа студија беше да се утврди просечната вредност на мозочната сатурација (rSO2) кај буден пациент (предоперативно) и нејзиното пероперативно движење во текот на умерена хипотензивна анестезија.

Исто така, целта беше да се одреди поврзаноста меѓу средниот артериски притисок (МАР) и мозочната сатурација (rSO2) во текот на умерената хипотензивна анестезија, како и да се согледаат можните несакани постоперативни последици (хипотензија,хипоксија) во собата за будење преку одредување на Алдрете Скор-от за будност на пациентот.

\section{Материјал и методи}

По добиената дозвола од Институционалната Етичка комисија, студијата се изведе во ГОБ „8-ми Септември” Скопје во која беа вклучени 20 пациенти примени за септопластика и ринопластика.

Критериуми за вклучување: ACA1 (здрави) пациенти во класификациона група (класификација на физичкиот статус на пациентот пред операција од Американското здружение на анестезиолози, бодирано од 1 до 5), возраст од 18-50 години, тежина во граница на БМИ од 18,5-30 кг/м², примени за септо- и ринопластика.

Критериуми за исклучување: хронични белодробни и кардиоваскуларни заболувања, алергија на ремифентанил и други анестетици, тешка хипотензија (MAP < од $50 \mathrm{mmHg}$ ) во тек на хируршката интервенција, ниска почетна базална вредност на мозочната сатурација
(rSO2) $<50 \%$ и анемија, (Hct $<30, \mathrm{Hgb}<10$ $\mathrm{gr} / \mathrm{dl})$. Во студијата беа вклучени сите пациенти кои по сите направени анализи, како и добиена информирана согласност, ги исполнуваа горенаведените критериуми за вклучување.

Премедикација и анестезиолошки протокол:

Триесет минути пред воведот во анестезија сите пациенти добија премедикација со апаурин 10mg и атропин 0,5mg интрамускулно; иинтравенозно преку канила се постави инфузија со 500мл физиолошки раствор. Мозочната сатурација (rSO2) беше мерена на двете мозочни хемисфери со поставување на лева и десна електрода на челото на пациентот 1 см над веѓите и 1 см латерално од средната линија на челото.

Воведот во анестезија беше со фента-

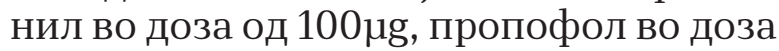
од $2-2,5 \mathrm{mg} / \mathrm{kg}$, а мускулна релаксација со рокурониум $0,5 \mathrm{mg} / \mathrm{kg}$. Во студијата како средство за постигнување на хипотензија во тек на општата анестезија беше користен краткодејствувачкиот опиоиден аналгетик ремифентанил администриран во континуирана интравенска инфузија веднаш по интубација, спремен во шприц пумпа во доза од $50 \mu \mathrm{g} / \mathrm{ml}$ и се дозираше со почетна доза од $0,5 \mu \mathrm{g} / \mathrm{kg} / \mathrm{min}$ со менување на дозата до постигнување и одржување на посакуваниот среден артериски притисок од 60-80 mmHg кај предоперативно нормотензивни пациенти. Анестезијата се одржуваше со анестетички гасови $\mathrm{O} 2$ и $\mathrm{N} 2 \mathrm{O}$ во однос 50:50, со проток од 6l/min и севофлуран 1-2Vol\%. По интубација и подготовка на оперативното поле, горниот дел од телото на секој пациент беше поткренат за 30о. Реверзија на блокот се вршеше со простигмин 2,5mg и атропин $1 \mathrm{mg}$ интравенски.

\section{Мониторинг:}

- Неинвазивно мерење на среден артериски притисок (МАР)

- Пулсна фреквенција на срцето (HR)

- Периферна сатурација на крв со 
кислород (SpO2)

- Електрокардиографија (EKG)

- Ендекспираторна концентрација на јаглерод диоксид (etCO2)

- Мозочната сатурација (rSO2) беше мерена на двете мозочни хемисфери со помош на INVOSTM 5100, а мозочниот оксиметар користи инфрацрвено светло со бранова должина од 730-810 nm. Секоја електрода ја мереше вредноста на мозочната сатурација на истостраната мозочна хемисфера. Почетната вредност на мозочната сатурација одредена на буден пациент кој дише собен воздух се поставуваше како базална вредност и во однос на неа на мониторот се следеше секоја понатамошна промена на мозочната сатурација, континуирано на дисплејот во облик на крива како и секоја промена на сатурацијата во однос на почетната вредност одредена во проценти (\%).

Временски интервали на мерење:

- Т1 - пред вовед во анестезија, пред оксигенација на болниот

- Т2 - по вовед во анестезија

- Т3 - 10 минути по вовед во анестезија, со вклучен ремифентанил исевофлуран, и поткренат горен

\section{дел од телото за 300}

- Т4 - 30 минути по вовед во анестезија

- T5 - буден пациент, по екстубација во сала

Постоперативно во соба за будење, 10 минути по изнесување на пациентот беше одреден модифицираниот Алдрете Скоринг систем при што се одредуваше периферната сатурација, моторната активност, свесноста, респирацијата и артерискиот притисок кај пациентите, бодирана од 0-2 за секој параметар.

\section{Резултати}

Вкупниот број испитаници во ова истражување изнесуваше 20, од кои мажи беа 10 (50\%) наспроти жени 10 (50\%),

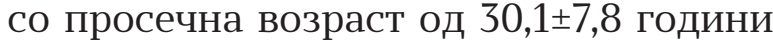
(мин. 21, макс. 51). Испитаниците беа со просечна тежина од 73,1 $\pm 12,7$ кг (мин. 50, макс. 97). Просечната вредност на БМИ беше 25ะ3,4 кг/м2 (мин. 19,3, макс. 29,9).

Во рамките на истражувањето беше направена анализа на вредностите на MAP во пет времиња на мерење (табела бр. 1). Притоа беа земени средната, максималната и минималната вредност, како и стандардната девијација.

Дополнителната анализа, за $\mathrm{p}<0,05$,

Табела 6р. 1. Анализа на примерокот по вредности на МАР во пет времиња на мерење

\begin{tabular}{|c|c|c|c|c|c|}
\hline $\begin{array}{c}\text { МАР во пет } \\
\begin{array}{c}\text { времиња на } \\
\text { мерење }\end{array}\end{array}$ & $\begin{array}{c}\text { Број } \\
\mathrm{N}\end{array}$ & $\begin{array}{c}\text { Минимум } \\
\text { (Min) }\end{array}$ & $\begin{array}{c}\text { Максимум } \\
\text { (Мах) }\end{array}$ & $\begin{array}{c}\text { Просек } \\
\text { (Меans) }\end{array}$ & $\begin{array}{c}\text { Стандардна } \\
\text { девијација } \\
\text { (Std.Dev.) }\end{array}$ \\
\hline MAP1 & 20 & 74 & 114 & $92,80^{\star}$ & 9,77 \\
\hline MAP2 & 20 & 67 & 114 & $91,55^{\star}$ & 14,01 \\
\hline MAP3 & 20 & 59 & 102 & $77,75^{*}$ & 11,37 \\
\hline MAP4 & 20 & 55 & 84 & $69,05^{\star}$ & 7,09 \\
\hline MAP5 & 20 & 82 & 117 & $97,40^{\star}$ & 9,13 \\
\hline
\end{tabular}

Friedman test: $\mathrm{N}=20$ Chi-Square $=46,683 ; \mathrm{df}=4 ; \mathrm{p}=0,00001^{*} \quad$ * сигнификантно за $\mathrm{p}<0,05$ 
укажа на сигнификантна разлика помеѓу просечните вредности на МАР во петте времиња на мерење (Friedman test: $\quad \mathrm{N}=20 \quad$ Chi-Square $=46,683 ; \quad \mathrm{df}=4$; $\mathrm{p}=0,00001$ ) (табела 1).

Анализата на измерените вредности на срцевата фреквенција (HR) во пе- тте времиња на мерење е дадена во табелата 2. Дополнителната анализа, за $\mathrm{p}<0,05$, укажа на сигнификантна разлика помеѓу просечните вредности на HR во петте времиња на мерење (Friedman test: $\mathrm{N}=20$ Chi-Square $=21,730$; $\mathrm{df}=4 ; \mathrm{p}=0,00001)$ (табела бр. 2).

Tабела 6р. 2. Анализа на примерокот по вредности на HR во пет времиња на мерење

\begin{tabular}{|c|c|c|c|c|c|}
\hline $\begin{array}{c}\text { НR во пет } \\
\text { времиња на } \\
\text { мерење }\end{array}$ & $\begin{array}{c}\text { Број } \\
\mathrm{N}\end{array}$ & $\begin{array}{c}\text { Минимум } \\
\text { (Min) }\end{array}$ & $\begin{array}{c}\text { Максимум } \\
\text { (Мах) }\end{array}$ & $\begin{array}{c}\text { Просек } \\
\text { (Means) }\end{array}$ & $\begin{array}{c}\text { Стандардна } \\
\text { девијација } \\
\text { (Std.Dev.) }\end{array}$ \\
\hline HR1 & 20 & 58 & 108 & $81,60^{*}$ & 15,16 \\
\hline HR2 & 20 & 66 & 118 & $90,70^{\star}$ & 12,74 \\
\hline HR3 & 20 & 58 & 114 & $81,00^{\star}$ & 14,91 \\
\hline HR4 & 20 & 52 & 121 & $72,65^{\star}$ & 16,57 \\
\hline HR5 & 20 & 70 & 108 & $86,10^{\star}$ & 12,27 \\
\hline
\end{tabular}

Friedman test: $\mathrm{N}=20$ Chi-Square=21,730; $\mathrm{df}=4 ; \mathrm{p}=0,00001^{*} \quad$ * сигнификантно за $\mathrm{p}<0,05$

Од добиените вредности на средниот артериски притисок (МАР) и срцевата фреквенција (HR) може да се види дека најниски измерени вредности имаше во четвртото време на мерење, односно периодот кога се прават остеотомиите на назалните коски, односно кога беше постигната умерена хипотензија.

Анализата на измерените вредности на мозочната сатурација (rSO2) на левата мозочна хемисфера (rSO2L) во петте времиња на мерење е прикажана во табелата бр. 3.

Табела 6p. 3. Анализа на примерокот по вредности на rSO2L во пет времиња на мерење

\begin{tabular}{|c|c|c|c|c|c|}
\hline $\begin{array}{c}\text { rSO2L во пет } \\
\text { времиња на } \\
\text { мерење }\end{array}$ & $\begin{array}{c}\text { Број } \\
\mathrm{N}\end{array}$ & $\begin{array}{c}\text { Минимум } \\
\text { (Min) }\end{array}$ & $\begin{array}{c}\text { Максимум } \\
\text { (Мах) }\end{array}$ & $\begin{array}{c}\text { Просек } \\
\text { (Меаns) }\end{array}$ & $\begin{array}{c}\text { Стандардна } \\
\text { девијација } \\
\text { (Std.Dev.) }\end{array}$ \\
\hline $\mathrm{rSO}_{2} \mathrm{~L} 1$ & 20 & 63 & 86 & $73,30^{\star}$ & 5,44 \\
\hline $\mathrm{rSO}_{2} \mathrm{~L} 2$ & 20 & 62 & 95 & $82,60^{\star}$ & 9,07 \\
\hline $\mathrm{rSO}_{2} \mathrm{~L} 3$ & 20 & 61 & 92 & $79,50^{\star}$ & 7,71 \\
\hline $\mathrm{rSO}_{2} \mathrm{~L} 4$ & 20 & 61 & 92 & $78,90^{\star}$ & 7,60 \\
\hline $\mathrm{rSO}_{2} \mathrm{~L} 5$ & 20 & 61 & 95 & $80,75^{\star}$ & 9,92 \\
\hline
\end{tabular}

Friedman test: $\mathrm{N}=20$ Chi-Square=21,730; $\mathrm{df}=4 ; \mathrm{p}=0,00001^{*} \quad$ * сигнификантно за $\mathrm{p}<0,05$ 
Дополнителната анализа, за $\mathrm{p}<0,05$, укажа на сигнификантна разлика помеѓу просечните вредности на rSO2L во петте времиња на мерење (Friedman test: $\quad \mathrm{N}=20 \quad$ Chi-Square $=32,146 ; \quad \mathrm{df}=4$; $\mathrm{p}=0,00001)$ (табела 3).

Анализата на измерените вредности на мозочната сатурација (rSO2) на десна- та мозочна хемисфера (rSO2D) во петте времиња на мерење е прикажана во табелата 6р. 4. Дополнителната анализа, за $\mathrm{p}<0,05$, укажа на сигнификантна разлика помеѓу просечните вредности на rSO2D во петте времиња на мерење (Friedman test: $\mathrm{N}=20$ Chi-Square $=28,914$; $\mathrm{df}=4 ; \mathrm{p}=0,00001)$ (табела бр. 4).

Табела 6p. 4. Анализа на примерокот по вредности на rSO2D во пет времиња на мерење

\begin{tabular}{|c|c|c|c|c|c|}
\hline $\begin{array}{c}\text { rSO2D во пет } \\
\text { времиња на } \\
\text { мерење }\end{array}$ & $\begin{array}{c}\text { Број } \\
\mathrm{N}\end{array}$ & $\begin{array}{c}\text { Минимум } \\
\text { (Min) }\end{array}$ & $\begin{array}{c}\text { Максимум } \\
\text { (Мах) }\end{array}$ & $\begin{array}{c}\text { Просек } \\
\text { (Mеans) }\end{array}$ & $\begin{array}{c}\text { Стандардна } \\
\text { девијација } \\
\text { (Std.Dev.) }\end{array}$ \\
\hline rSO2D1 & 20 & 67 & 86 & $75,30^{\star}$ & 5,18 \\
\hline rSO2D2 & 20 & 67 & 95 & $83,70^{*}$ & 8,03 \\
\hline rSO2D3 & 20 & 65 & 95 & $81,35^{*}$ & 8,86 \\
\hline rSO2D4 & 20 & 68 & 92 & $80,00^{*}$ & 7,97 \\
\hline rSO2D5 & 20 & 66 & 95 & $81,95^{*}$ & 7,98 \\
\hline
\end{tabular}

Friedman test: $\mathrm{N}=20$ Chi-Square=28,914; $\mathrm{df}=4 ; \mathrm{p}=0,00001^{*} \quad$ * сигнификантно за $\mathrm{p}<0,05$

Од табелите 3 и 4 може да се види дека просечната измерена вредност на мозочната сатурација (во Т1) кај нашите испитаници изнесуваше

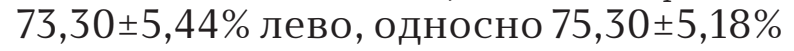
десно.
Тестираната разлика во просечните вредности на rSO2L1 во однос на просечните вредности на rSO2L2; rSO2L3 rSO2L4; и rSO2L5, за $\mathrm{p}<0,05$, укажа на сигнификантна разлика во сите испитувани комбинации во прилог на највисоки просечни вредности во Т2 (rSO2L1/rSO2L2) (табела бр. 5).

Табела 6p. 5. Според6а на просечни вредности на rSO2L1 co rSO2L во четири времиња

\begin{tabular}{|c|c|c|c|c|c|c|c|c|}
\hline & \multicolumn{5}{|c|}{ Paired Differences } & \multirow{3}{*}{$\mathrm{t}$} & \multirow{3}{*}{ Df } & \multirow{3}{*}{$\begin{array}{l}\text { Sig. } \\
\text { (2-tailed) }\end{array}$} \\
\hline & \multirow[t]{2}{*}{ Mean } & \multirow{2}{*}{$\begin{array}{l}\text { Std. Devi- } \\
\text { ation }\end{array}$} & \multirow{2}{*}{$\begin{array}{l}\text { Std. Error } \\
\text { Mean }\end{array}$} & \multicolumn{2}{|c|}{$\begin{array}{l}95 \% \text { Confidence Inter- } \\
\text { val of the Difference }\end{array}$} & & & \\
\hline & & & & Lower & Upper & & & \\
\hline rSO2L1 - rSO2L2 & $(9,300)$ & 5,921 & 1,324 & $(12,071)$ & $(6,529)$ & $(7,024)$ & 19 & $0,000^{*}$ \\
\hline rSO2L1 - rSO2L3 & $(6,200)$ & 4,652 & 1,040 & $(8,377)$ & $(4,023)$ & $(5,960)$ & 19 & $0,000^{*}$ \\
\hline rSO2L1 - rSO2L4 & $(5,600)$ & 4,893 & 1,094 & $(7,890)$ & $(3,310)$ & $(5,119)$ & 19 & $0,000^{*}$ \\
\hline rSO2L1 - rSO2L5 & $(7,450)$ & 6,692 & 1,496 & $(10,582)$ & $(4,318)$ & $(4,978)$ & 19 & $0,000^{*}$ \\
\hline
\end{tabular}

* сигнификантно за $\mathrm{p}<0,05$ 
Тестираната разлика во просечните вредности на rSO2D1 во однос на просечните вредности на rSO2D2,rSO2D3, rSO2D4 и rSO2D5, за $p<0,05$, укажа на сигнификантна разлика во сите испитувани комбинации во прилог на највисоки просечни вредности во T2( rSO2D1/ rSO2D2) (табела 6). Измерената вредност на мозочната сатурација, и лево, и десно, како и разликата во однос на почетната вредност по времињата на мерење беше највисока во Т2, односно веднаш по воведот во анестезија и се совпаѓаше со давањето анестетици (табели 6р. 5 и 6). Во понатамошниот тек на мерење на вредностите на мозочната сатурација, разликата во однос на почетната вредност остана статистички значајна, но со тренд на опаѓање. Од табелата 1 се гледа дека во Т3 и Т4 беа измерени најниски вредности на средниот артериски притисок $(77,75 \pm 11,37$, односно 69,05 $\pm 7,09)$, што е во граници на умерена хипотензија.

Табела 6р. 6. Споредба на просечни вредности на rSO2D1 co rSO2D во четири времиња

\begin{tabular}{|c|c|c|c|c|c|c|c|c|}
\hline & \multicolumn{5}{|c|}{ Paired Differences } & \multirow{3}{*}{$\mathrm{t}$} & \multirow{3}{*}{$\mathrm{Df}$} & \multirow{3}{*}{$\begin{array}{c}\text { Sig. } \\
\text { (2-tailed) }\end{array}$} \\
\hline & \multirow[t]{2}{*}{ Mean } & \multirow{2}{*}{$\begin{array}{l}\text { Std. Devi- } \\
\text { ation }\end{array}$} & \multirow{2}{*}{$\begin{array}{l}\text { Std. Error } \\
\text { Mean }\end{array}$} & \multicolumn{2}{|c|}{$\begin{array}{l}\text { 95\% Confidence Inter- } \\
\text { val of the Difference }\end{array}$} & & & \\
\hline & & & & Lower & Upper & & & \\
\hline rSO2D1 - rSO2D2 & $(8,400)$ & 5,651 & 1,264 & $(11,045)$ & $(5,755)$ & $(6,647)$ & 19 & $0,000^{\star}$ \\
\hline rSO2D1 - rSO2D3 & $(6,050)$ & 6,253 & 1,398 & $(8,977)$ & $(3,123)$ & $(4,327)$ & 19 & $0,000^{\star}$ \\
\hline rSO2D1 - rSO2D4 & $(4,700)$ & 5,151 & 1,152 & $(7,111)$ & $(2,289)$ & $(4,080)$ & 19 & $0,001^{*}$ \\
\hline rSO2D1 - rSO2D5 & $(6,650)$ & 5,518 & 1,234 & $(9,233)$ & $(4,067)$ & $(5,389)$ & 19 & $0,000^{*}$ \\
\hline
\end{tabular}

* сигнификантно за $\mathrm{p}<0,05$

Во табелата бр. 7 е дадена корелацијата помеѓу MAP, rSO2L и rSO2D во четирите времиња со користење на Spearman Rank Order Correlations.

Табела 6p. 7. Анализа на примерокот по вредности на rSO2D во пет времиња на мерење

\begin{tabular}{|c|c|c|}
\hline & rSO2L2 & rSO2D2 \\
\hline \multirow{2}{*}{ MAP2 } & $\begin{array}{c}\text { Spearman Rank Order Correlations : } \\
\mathrm{R}=0,259\end{array}$ & $\begin{array}{c}\text { Spearman Rank Order Correlations : } \\
\mathrm{R}=0,339\end{array}$ \\
\hline & rSO2L3 & rSO2D3 \\
\hline \multirow{2}{*}{ MAP3 } & $\begin{array}{c}\text { Spearman Rank Order Correlations : } \\
\mathrm{R}=0,275\end{array}$ & $\begin{array}{c}\text { Spearman Rank Order Correlations : } \\
\mathrm{R}=0,597\end{array}$ \\
\hline & rSO2L4 & rSO2D4 \\
\hline \multirow{2}{*}{ MAP4 } & Spearman Rank Order Correlations : & $\begin{array}{c}\text { Spearman Rank Order Correlations : } \\
\mathrm{R}=0,215\end{array}$ \\
\hline & rSO2L5 & $\mathrm{rSO2D5}$ \\
\hline \multirow{2}{*}{ MAP5 } & $\begin{array}{c}\text { Spearman Rank Order Correlations : } \\
\mathrm{R}=0,499\end{array}$ & $\begin{array}{c}\text { Spearman Rank Order Correlations : } \\
\mathrm{R}=0,629\end{array}$ \\
\hline
\end{tabular}


Од табелата бр. 7 може да се види дека во Т2, Т3 и Т4 постоеше слаба до умерена позитивна корелација помеѓу измерените вредности на MAP corSO2L и rSO2D, што значи како се намалуваше измерената вредност на средниот артериски притисок така се намалуваше и вредноста на мозочната сатурација. Но, за цело време вредноста на измерената мозочна сатурација и лево и десно беше повисока од базалната, почетната измерена вредност на истата. Во Т5 постоеше јака позитивна корелација помеѓу просечната вредност на средниот артериски притисок и мозочната сатурација, односно лево за $\mathrm{R}=0,499$, десно за $\mathrm{R}=0,629$.

Просечната вредност на Алдрете Скорот оценета постоперативно во собата за будење изнесуваше $9,8 \pm 0,4$, со минимална вредност од 9 и максимална вредност од 10 (табела бр. 8).

Табела 6р. 8. Дескриптивна анализа на примерокот за Aldrete Score системот

\begin{tabular}{|c|c|c|c|c|c|}
\hline $\begin{array}{c}\text { Селектирани } \\
\text { параметри }\end{array}$ & $\begin{array}{c}\text { Број } \\
\mathrm{N}\end{array}$ & $\begin{array}{c}\text { Минимум } \\
\text { (Min) }\end{array}$ & $\begin{array}{c}\text { Максимум } \\
\text { (Max) }\end{array}$ & $\begin{array}{c}\text { Просек } \\
\text { (Means) }\end{array}$ & $\begin{array}{c}\text { Стандардна } \\
\text { девијација } \\
\text { (Std.Dev.) }\end{array}$ \\
\hline AldreteScore & 20 & 9 & 10 & 9,85 & 0,37 \\
\hline
\end{tabular}

\section{Дискусија}

Крвниот притисок е еден од најбитните витални знаци којшто се мониторира во текот на анестезијата, а со цел да се обезбеди добра ткивна перфузија на виталните органи.Нормотензивната анестезија е златен стандард, но хипотензивната анестезија како анестезиолошка техника има свое место при одредени хируршки интервенции, каде зголеменото крвавење води кон лоши услови за работа, продолжено време на операција и продолжен престој на болниот во болница. Како и да е, хипотензивната анестезија може да доведе до намалена перфузија на виталните органи, како што се срцето, бубрезите и мозокот ${ }^{31}$.

Во нашата студија пациентите беа воведени и одржувани во умерена хипотензија со континуирана апликација на ремифентанил, заедно со севофлуран со цел одржување на посакуваната хипотензија. Покрај стандардниот мониторинг, беше користен и NIRS мониторот со кој се следеше мозочната сатурација на двете мозочни хемисфери. Целта беше да се одржува добра мозочна сатурација, во текот на индуцираната хипотензија да се превенира падот на мозочната сатурација под препорачаните вредности, како и из- наоѓање поврзаност помеѓу вредноста на средниот артериски притисок (MAP) и мозочната сатурација (rSO2).

Од анализата на добиените вредности на средниот артериски притисок (MAP) и срцевата фреквенција (HR) во петте времиња на мерење може да се види дека најниски измерени вредности постоеја во четвртото време на мерење (табели бр.1 и 2). Постигнатата умерена хипотензија (МАР $=69,05 \pm 7,09$, $\mathrm{HR}=72,65 \pm 16,57)$ беше во границите на препорачаните вредности за умерена хипотензија (60-80 mmHg), и статистички значајно пониска во однос на почетните предоперативно измерени вредности $(\mathrm{p}<0,05)$.

Што се однесува до добиените вредности за мозочната сатурација во нашата студија, од табелите 3 и 4 може да се види дека просечната базална вредност на мозочната сатурација (Т1) измерена кај буден пациент на собен воздух, кај нашите испитаници изнесуваше 73,30 \pm 5,44\% лево (мин. 63, макс. 86), односно 75,30ะ5,18\% десно (мин. 67, макс. 86), што е во граница на препорачаните нормални вредности. Madsen и соработниците ${ }^{32}$ ја дефинирале нормалната граница на вредноста на мозочната сатурација од 55\% до 78\% и нашле видливо намалување на 
вредноста кај пациенти со акутна срцева слабост (од 20\% до 58\%). Kim и соработниците 33ја испитувале базалната вредност кај млади луѓе на возраст од 20-36 години и дошле до вредност од $71 \pm 6 \%$.Edmonds и соработниците ${ }^{30}$, кај пациенти на возраст од 20-90 години подложни на кардиохируршка интервенција нашле вредност на мозочната сатурација од $67 \pm 10 \%$. Casati и соработниците ${ }^{20}$ кај здрави пациенти кои биле подложени на некардиохируршки интервенции нашле вредност од $63 \pm 8 \%$. Kim и соработниците 33 во 5,4\% од испитуваната популација нашле вредност на rSO2<50\%, а кај $1,6 \%$ од испитаниците вредност на $\mathrm{rSO} 2<40 \%$. Kishi и copaботниците ${ }^{34}$ ги испитувале хируршките пациенти и влијанието на демографските карактеристики врз мозочната сатурација, при што дошле до заклучок дека не постои поврзаност со висината, тежината, обемот на глава и пол, но постои негативна корелација со возраста, а позитивна корелација со вредноста на хемоглобинот. Misra и соработниците ${ }^{35}$, пак, не нашле поврзаност помеѓу вредноста на мозочната сатурација и возраста, полот, бојата на кожа, висината, тежината, пушењето и консумирањето кофеин кај 94 возрасни здрави испитаници. Притоа разликата во мозочната сатурација помеѓу левата и десната мозочна хемисфера во нашите резултати беше незначителна, со нешто повисока вредност на десната хемисфера.

Во понатамошниот тек движењето на вредноста на мозочната сатурација во двете мозочни хемисфери во тек на општата хипотензивна анестезија имаше свој карактеристичен тек.

Кај сите наши испитаници кривата на мозочната сатурација на почетокот имаше нагорен тренд, односно пик којшто се совпаѓаше со моментот на давање анестетици и воведот во општа анестезија (табели 3 и 4). Притоа, измерената вредност на мозочната сатурација, и лево, и десно, како и разликата по времињата на мерење во однос на почетната кај буден пациент беше највисока во Т2 (табели 5 и 6), односно веднаш по воведот во анестезија, што може да се објасни со ефектот на анестетиците на мозокот. Тоа се совпаѓа со резултати добиени во други студии. Во студијата на Hernandez-Meza ${ }^{17}$, тоа е објаснето со ефектот на анестетиците на мозокот кои го намалуваат мозочниот крвен проток (Cerebral blood flow-CBF), но и мозочната потрошувачка на кислород (Cerebral metabolic rate-CMRO2) во зависност од дадената доза, заради глобалното намалување на невронската активност на мозокот, со што се зголемува вредноста на мозочната сатурација. Niessen и соработниците ${ }^{36}$ го испитувале ефектот на намалување на средниот артериски притисок врз вредноста на мозочната сатурација при вовед во анестезија со пропофол и фентанил, при што дошле до заклучок дека вредноста на мозочната сатурација сигнификантно се зголемува со намалување на вредноста на средниот артериски притисок во тек на воведот во општа анестезија.Lovell и соработниците ${ }^{37}$ нашле мала промена во мозочната сатурација при вовед во општа анестезија со три различни интравенски анестетици, пропофол, тиопентал и етомидат, следејќи ги хемодинамските промени во првите три минути од воведот. Притоа, пропофол и тиопентал ја зголемиле вредноста на мозочната сатурација, додека етомидат ја намалил мозочната сатурација. Fleck и соработниците ${ }^{38}$ го испитувале ефектот на пропофол врз мозочната сатурација при вовед во анестезија, но во педијатриска популација, при што добиле значајно зголемување на вредноста на мозочната сатурација во тек на воведот во општа анестезија.

Во понатамошниот тек на мерење на вредностите на мозочната сатурација, во тек на хипотензивната анестезија и разликата во однос на почетната вредност кај буден пациент, од нашите резултати се гледа дека разликата остана и понатаму статистички значајна но со тренд на постепено опаѓање, што го објаснивме со водењето на пациентот во умерена хипотензија, што беше и наша цел во студијата. Од табелите 5 и 6 се гледа дека во Т4, моментот каде што е најнизок средниот артериски притисок, најмала беше и разликата помеѓу добиената вредност на мозочната сатурација во однос на почетната, базална вредност во Т1. Во Т5, времето 
по завршување на хируршката интервенција, пациентот беше разбуден и екстубиран и оксигениран на маска со O2 со проток од $6 \mathrm{l} / \mathrm{min}$. Средниот артериски притисок беше со вредност повисока од периодот на хипотензија, а исто така и вредноста на мозочната сатурација беше повисока од вредноста измерена во периодот на хипотензивната анестезија поради дополнителната кислородна оксигенација на буден пациент.

Во табелата бр. 7 е дадена корелацијата помеѓу просечните вредности на средниот артериски притисок и мозочната сатурација лево и десно во Т2, T3, Т4 и Т5 со користење на Spearman Rank Order Correlations. Може да се види дека во Т2, Т3 и Т4 постоеше слаба до умерена позитивна корелација помеѓу измерените вредности на средниот артериски притисок и мозочната сатурација лево и десно, што значи како се намалуваше вредноста на средниот артериски притисок така се намалуваше и вредноста на мозочната сатурација. Во T5 постоеше јака позитивна корелација помеѓу просечната вредност на средниот артериски притисок и мозочната сатурација, односно лево за $\mathrm{R}=0,499$, а десно за $\mathrm{R}=0,629$.

На крај, од нашите добиени резултати може да се види дека за цело време вредноста на измерената мозочна сатурација и лево и десно за време на општата анестезија беше повисока од базалната, почетна измерена вредност на буден пациент, што можеме да го објасниме со добрата седација на пациентот и намалената потрошувачка на кислород во мозокот. Според Liu R и соработниците ${ }^{39}$ стабилноста на средниот артериски притисок и мозочната сатурација за време на критичниот период на хируршката интервенција е овозможена од добрата мозочна авторегулација, но за секој пациент индивидуално.

Важно е да се напомене дека интраоперативно кај нашите пациенти не беше регистриран пад на средниот артериски притисок под дозволените $50 \mathrm{~mm} \mathrm{Hg}$, ниту пад на мозочната сатурација повеќе од дозволените 20\% од почетната,базална вредност кај буден пациент.
Постоперативно во собата за будење не беа регистрирани какви било компликации од водењето на пациентите во хипотензивна анестезија и просечната вредност на Алдрете Скор-от оценета постоперативно, односно просечната вредност изнесуваше 9,8土0,4, со минимална вредност од 9 и максимална вредност од 10 (табела бр. 8).

\section{Заклучоци}

Од нашата студија може да се заклучи дека умерената хипотензија индуцирана со ремифентанил и севофлуран ја подобрува ткивната оксигенација, како и мозочната сатурација (rSO2) кај пациентите во општа анестезија подложени на рино/септопластики и дека постои позитивна корелација помеѓу вредноста на средниот артериски притисок (MAР) и вредноста на мозочната сатурација (rSO2).

Стабилниот среден артериски притисок (MAР) во тек на умерената хипотензија придонесе за стабилна мозочна сатурација (rSO2) во тек на општата анестезија, бескрвно оперативно поле и добри услови за работа на операторот/хирургот, како и хемодинамски стабилни и будни пациенти постоперативно во собата за будење.

Врз основа на ова истражување може да се даде препораката дека е потребен задолжителен мониторинг на ткивната и мозочната сатурација во текот на општа анестезија, особено при индуцирана умерена хипотензивна техника, a cè со цел да се овозможи поголема безбедност на пациентите и поголема сигурност на анестезиологот.

\section{Референци}

1. Rodrigo C. Induced hypotension during anesthesia with special reference to orthognathic surgery. Anesth Prog 1995;42(2):41-5.

2. Enderly GEH. Controlled Hypotension.Anesthesia. 1960;15:25-32.

3. Fromme GA, MacKenzie RA, Gould Jr AB,Lund BA,Offord K.Controlled hy- 
potension for orthognathic surgery. Anesth \& Analges 1986;65(6):683-86

4. Patel NJ,Patel BS,Paskin S,Laufer S. Induced moderate hypotensive anesthesia for spinal fusion and Harrington-rod instrumentation. J Bone Joint Surg Am 1985;67(9):1384-87

5. Barak M,Yoav L, Abu el-Naaj I. Hypotensive Anesthesia versus Normotensive Anesthesia during Major Maxillofacial Surgery: A Review of the Literature. The Scientific World Journal. 2015; 1-7

6. Albera $\mathrm{R}$ et al. Cochlear blood flow modifications induced by anaesthetic drugs in middle ear surgery: comparison between sevoflurane and propofol. Acta oto-laryngologica 2003; 123(7):812-16

7. Eberhart LH, Folz BJ, Wulf H, Geldner G. Intravenous anesthesia provides optimal surgical conditions during microscopic and endoscopic sinus surgery. The Laryngoscope 2003; 113(8):1369-73

8. Seruya $\mathrm{M}$ et al. Controlled hypotension and blood loss during frontoorbital advancement: Clinical article. Journal of Neurosurgery 2012;9(5):49196

9. Činčikas D, Ivaškevičius J. Application of controlled arterial hypotension in endoscopic rhinosurgery. Medicina 2003;39(9):852-59

10. Shirgoska B. Hipotensive anesthesia. Skopje, Ph Thesis, Faculty of Medicine, Saints Cyril and Methodius University of Skopje, Skopje, 2012

11. Degoute CS. Controlled hypotension. Drugs 2007; 67:1053-76

12. Vilke A. Near-infrared spectroscopy as an index of brain and tissue oxygenation. Health Sciences 2011;21:143-151

13. Murkin JM, Arango M. Near-infrared spectroscopy as an index of brain and tissue oxygenation. $\mathrm{Br} \mathrm{J}$ of anaesth 2009;103: i3-i13

14. Soeding PF, Wang J, Hoy G, Jarman P, Phillips H, Marks P, Royse C. The effect of the sitting upright or ,beachchair" position on cerebral blood flow during anaesthesia for shoulder surgery. Anaesth Intensive Care 2011;39(3):440-8

15. Bouma GJ, Muize JP. Relationship between cardiac output and cerebral blood flow in patients with intact and with impaired autoregulation. J of Neurosurgery 1990;73(3):368-374

16. Rosner MJ, Daughton S. Cerebral perfusion pressure management in head injury. J Trauma 1990;30:933-941

17. Hernandez-Meza G, Izzetoglu M, Osbakken M. Near-Infrared spectroscopy for the evaluation of anesthetic depth. BioMed research international 2015;Id939418:11p

18. Pollard V, Prough DS, DeMelo AE, Deyo DJ, Uchida T, Stoddart HF. Validation in volunteers of a near-infrared spectroscope for monitoring brain oxygenation in vivo. Anesth Analg1996;82:269-277

19. Ferrari M, Giannini I, Sideri G, Zanette E. Continuous non invasive monitoring of human brain by near infrared spectroscopy. Oxygen Transport to Tissue VII 1985;191:872-882

20. Casati A, Fanelli G, Pietropaoli P, Proietti R, Tufano R, Danelli G, et al. Continuous monitoring of cerebral oxygen saturation in elderly patients undergoing major abdominal surgery minimizes brain exposure to potential hypoxia. Anesth Analg 2005;101(3):740-747

21. Janelle GM, Mnookin S, Gravenstein N, Martin TD, Urdaneta F. Unilateral cerebral oxygen desaturation during emergent repair of a DeBakey type 1 aortic dissection: potential aversion of a major catastrophe. Anesthesiology 2002;96:1263-1265.

22. Blas ML, Lobato EB, Martin T. Noninvasive infrared spectroscopy as a monitor of retrograde cerebral perfusion during deep hypothermia. J of cardiothoracic and vascular anesth 1999;13(2):244-245

23. Ohmae E, Ouchi Y, Oda M, Suzuki T, Nobesawa S, Kanno T et al. Cerebral hemodynamics evaluation by near-infrared time-resolved spectroscopy: 
correlation with simultaneous positron emission tomography measurements. Neuroimage 2006; 29(3):697705

24. Cullen DJ,Kirby RR. Beach chair position may decrease cerebral perfusion: catastrophic outcomes have occurred. APSF newsletter 2007; 22(2):25-27

25. Pollard V, Prough DS, De Melo AE, Deyo DJ. The influence of carbon dioxide and body position on near infrared spectroscopic assessment of cerebral hemoglobin oxygen saturation. Anesth Analg 1996;82(2):278-287

26. Han SH, Ham BM, Oh YS, Bahk JH. The effect of acute normovolemic haemodilution on cerebral oxygenation. International journal of clinical practice 2004; 58(10):903-906

27. Naidech AM, Bendok BR, Ault ML, Bleck TP. Monitoring with the Somanetics INVOS 5100C after aneurysmal subarachnoid hemorrhage. Neurocritical care 2008;9(3):326-331

28. Nieman JD et al. Deep hypothermia alters the vascular response to Thiopental. Anesthesiology 2002;96:A 169

29. Rosner MJ, Coley IB. Cerebral perfusion pressure, intracranial pressure, and head elevation. Journal of neurosurgery 1986;65(5):636-641

30. Edmonds HL Jr, Brian LG, Erle HA 11l. Cerebral oximetry for cardiac and vascular surgery, Seminars in Cardiothoracic \& Vascular. Anesthesia 2004;8(2):147-166

31. Strunin L. Organ perfusion during controlled hypotension. Br J Anaesth. 1975;47(7):793-8.

32. Madsen PL, Nielsen HB, Christiansen P. Well-being and cerebral oxygen saturation during acute heart failure in humans. Clin Physiol 2000; 20(2):15864

33. Kim MB, Ward DS, Cartwright CR. et al. Estimation of jugular venous $\mathrm{O} 2$ saturation from cerebral oximetry or arterial $\mathrm{O} 2$ saturation during isocapnic hypoxia. Journal of clinical monitoring and computing 2000;16(3):191199
34. Kishi K, Kawaguchi M, Yoshitani K, Nagahata T, Furuya H. Influence of patient variables and sensor location on regional cerebral oxygen saturation measured by INVOS 4100 near-infrared spectrophotometers. J Neurosurg Anesthesiol 2003;15(4):302-6.

35. Mishra RK, Kapoor I, Mahajan C, Prabhakar H. Reversal of trend in near infrared spectroscopy [NIRS] values in a patient with carotid artery stenosis. J Clin Anesth 2017;43:47.

36. Nissen P, Van Lieshout JJ, Nielsen HB, Niels S. Frontal lobe oxygenation is maintained during hypotension following propofol-fentanyl anesthesia. AANA journal 2009; 77(4):271-276

37. Lovell AT, Owen-Reece H, Elwell CE, Smith M, Goldstone JC. Continuous measurement of cerebral oxygenation by near infrared spectroscopy during induction of anesthesia. Anesth Analg 1999;88(3):554-58

38. 3Fleck T, Schubert S, Ewert P, Stiller B, Nagdyman N, Berger F. Propofol effect on cerebral oxygenation in children with congenital heart disease. Pediatr Cardiol 2015;36(3):543-9

39. Liu R, Sun D, Hang Y, et al. Evaluation of cerebral oxygen balance by cerebral oximeter and transcranial Doppler during hypothermic. Anesthesiology 1998; 89:309 (abstract). 